\title{
The Clinical Utility of Induced Sputum for the Diagnosis of Bacterial Community-Acquired Pneumonia in HIV-Infected Patients: A Prospective Cross-Sectional Study
}

\author{
Rosemeri Maurici da Silva ${ }^{1}$, \\ Paulo José Zimermann Teixeira² \\ and José da Silva Moreira ${ }^{2}$
}

\author{
${ }^{1}$ South University of Santa Catarina (UNISUL), \\ Florianópolis, SC; ${ }^{2}$ Federal University of Rio \\ Grande do Sul, Porto Alegre, RS, Brazil
}

\begin{abstract}
Background. Bacterial pneumonias have been overcoming pneumocytosis in frequency. Controversy still remains about how to manage immunocompromised patients and those with lung diseases. Sputum analysis is a noninvasive and simple method, and when interpreted according to specific criteria it may help with diagnosis. We conducted a study to evaluate sensitivity, specificity, positive and negative predicted values, and the accuracy of induced sputum (IS) for bacterial communityacquired pneumonia diagnosis in HIV-positive patients.Material and Methods. This cross sectional study evaluated a diagnostic procedure in a reference hospital for HIV patients in Florianópolis, SC, Brazil. From January 1, 2001 to September 30, 2002, 547 HIV-positive patients were analyzed and 54 inpatients with pulmonary infection were selected. Bronchoalveolar lavage (BAL) and transbronchial lung biopsy (TBLB) were considered the gold standards. Gram stains and quantitative cultures of IS and BAL were obtained. The cut-offs for quantitative cultures were $10^{6} \mathrm{CFU} / \mathrm{mL}$ for IS and $10^{4} \mathrm{CFU} /$ $\mathrm{mL}$ for BAL. Results. The mean age was 35.7 years, $79.6 \%$ were males and $85.2 \%$ were caucasians. The mean lymphocyte count was $124.8 / \mathrm{mm}^{3}$. Bacterial pneumonia was diagnosed in 20 patients. The most prevalent bacteria was Streptococcus pneumoniae. Considering IS for the diagnosis of bacterial pneumonia, sensitivity was $60 \%$, specificity $40 \%$, the positive predictive value was $80 \%$, negative predictive value $20 \%$ and accuracy $56 \%$.Conclusion. IS with quantitative culture can be helpful for the diagnosis of bacterial pneumonia in HIV-positive patients.

Key Words: Induced sputum, HIV, bacterial pneumonia.

Abbreviations: BAL = bronchoalveolar lavage; TBLB = transbronchial lung biopsy; IS = induced sputum; CFU = colony forming units.
\end{abstract}

The HIV retrovirus infects lymphocytes $\mathrm{CD}_{4}^{+}$(LT4), or helper cells, and macrophages. The T-lymphocytes are important in the activation of B-lymphocytes and for the subsequent production of immune globulins, which are compromised by primary disorder of cellular immunity. Furthermore, function defects are observed in B-lymphocytes, leading to progressive loss in immunoglobulin-specific responses. The chemotatic process is also disturbed, resulting in a decrease of, or even absence of a granulomatosis reaction. Such disarrangement predisposes individuals to opportunistic infections and the etiological spectrum of diseases becomes practically infinite [1]. Also, an infection caused by HIV is a dynamic condition in which the immune status and the risks of specific etiological agents are altered with the passage of time, as well as during different stages of the illness [2].

Some studies have reported that bacterial pneumonias have become more frequent than pneumocystosis. Two or more episodes of bacterial pneumonia during one year is a criterion for AIDS diagnosis [3]. Isolation of Streptococcus pneumoniae reaches approximately 18 cases per 1000 patients/

Received on 07 December 2005; revised 31 March 2006.

Address for correspondence: Dr. Rosemeri Maurici da Silva. Rua Moçambique, 852, Rio vermelho, Zip code: 88060-415, Florianópolis, SC, Brazil.

The Brazilian Journal of Infectious Diseases 2006;10(2):89-93. (C) 2006 by The Brazilian Journal of Infectious Diseases and Contexto Publishing. All rights reserved. year, increasing the rate found in immunocompetent patients five-fold [4,5].

There is still controversy about how to handle immunocompromised patients with lung disease. Although each method has its limitations and risks, one should be able to choose the best procedure with lowest risk to obtain pulmonary secretions. Sputum analysis is a noninvasive method, and its macroscopic and microscopic interpretation according to specific criteria can help with diagnosis. Quantitative cultures with greater than $10^{6} \mathrm{CFU} / \mathrm{mL}$ help to distinguish infecting organisms from colonizers [6].

Considering that spontaneous expectoration is not produced by most patients [7], induced sputum (IS) should be used for such individuals. A body of evidence [8-11] shows its utility for the diagnosis of Pneumocystosis and Mycobateriosis, but for some other pathogens, especially pyogenic bacteria, information is rare.

We evaluated the utility of IS for the diagnosis of bacterial community-acquired pneumonia in HIV-infected patients.

\section{Material and Methods}

All HIV-positive patients, older than 14 years, admitted at Nereu Ramos Hospital (Florianópolis - SC), from January 1, 2001 to September 30, 2002, were evaluated and divided into two categories: patients presenting respiratory symptoms for seven or more days with or without lesions in chest X-rays and asymptomatic patients with alterations in the chest $\mathrm{x}$-ray [12]. 
Exclusion criteria were patients under empirical or prophylactic treatment for any pulmonary disease $[3,13]$ in the previous 30 days, any type of tuberculosis during the previous six months, Karnofski scale between 20 and 30 $[14,15]$, impaired consciousness or coma [16], blood clotting alterations [16], partial pressure of oxygen $<80 \mathrm{mmHg}$ receiving 2 liters/min [16] of supplementary oxygen via a nasal catheter, a reduction of more than $20 \%$ in FEV1 during sputum induction and/or signals and symptoms that were contraindicative for this procedure [17], non effective sputum induction and patients who refused to be part of study or who did not agree to the diagnostic procedures.

After signing the informed consent, all patients included were submitted to clinical, radiological and laboratorial investigations, and the data were recorded. Sputum induction and flexible bronchoscopy with bronchoalveolar lavage (BAL) and transbronchial lung biopsy (TBLB) were performed within 24 hours.

This study was approved by the Ethics Research Committee of Nereu Ramos Hospital.

Sputum induction. The sputum induced with a US-800 Air Standard ${ }^{\circledR}$ nebulizer, set at $1 \mathrm{~mL} /$ minute $+/-0.2$ rate, and 0.5 to 10 micrometers particle sizes, as specified by the manufacturer; a Microlab 3500Oे spirometer was used in accordance with the protocol described by Efthmiadis et al. [17]. The laboratory sputum samples were processed as follows [18]: a small portion of the most purulent or clotted part of the sputum was chosen in case of non purulent samples, transferred with a platinum wire loop and placed at one of the extremities of the slide. In order to eliminate saliva contamination of this material, the small portion of pus or clotted sputum was smeared to the other extremity of the slide. The remaining saliva in the slide was removed with a paper filter. The sputum portion remaining on the slide was distended and fixed for staining. The sputum sample was eligible if there were less than 10 squamous epithelial cells and more than 25 leukocytes per high-power microscopic field, as well as if alveolar macrophages were present [1822]. If a sample was considered unsatisfactory, a new one was obtained within 48 hours. Gram staining was done for pyogenic bacteria, Ziehl-Neelsen staining for acid-fast bacilli, potassium hydroxide clarification for fungi, Grocott-Gomori staining for Pneumocystis jiroveci and other fungi, Papanicolaou for the differential cell count, the cytopathological exam and viral inclusions in the cells. Cultures were also made for acid-fast resistant bacilli (Löwenstein-Jensen) and for fungi (Sabouraud agar), and quantitative cultures were made for pyogenic bacteria (blood agar and MacConkey agar) [19-21]. The cut off point for the quantitative cultures was $\geq 10^{6} \mathrm{CFU} / \mathrm{mL}$ [6].

Bronchoalveolar lavage. A flexible bronchoscopy with BAL and TBLB was carried out using an Olympus ${ }^{\circledR}, 2.6 \mathrm{~mm}$ diameter device. BAL samples were processed the same way as the sputum samples and were considered satisfactory if there were ciliated cells, alveolar macrophages and a maximum of $10 \%$ epithelial cells [23]. Whenever BAL samples were considered unsatisfactory, a new procedure was done within 48 hours to obtain new samples. Specimens of TBLB were analyzed using Hematoxylin-Eosin, Ziehl-Neelsen, and Grocott-Gomori colorations. An imprint was made using a tissue fragment for Gram stains. Three other tissue fragments were placed in saline for cultures in Löwenstein-Jensen, Sabourauds, blood agar and MacConkey agar media. [1921]. In case of unsatisfactory samples, e.g. without alveolar structures, a TBLB was repeated within 48 hours after the first procedure.

Bacterial pneumonia definition. The diagnostic criteria were the presence of infiltration and/or alveolar consolidation observed on chest x-ray or CT scan, associated with the presence of predominant bacterial morphotypes in Gram stain and a BAL quantitative culture $\geq 10^{4} \mathrm{CFU} / \mathrm{mL}$ and/or positive blood cultures, and/or identification of the agent in a Gram stain of the lung fragment of TBLB imprinted on the slide, and/or isolation of the agent cultured from lung tissue samples [4-6]. Values were expressed as the mean (M) and standard deviation (SD) (continuous variables) or as a percentage of the group from which they were derived (categorical variables) [24]. The sensitivity, the specificity, the positive and negative predicted values, and the accuracy of the IS were also determined $[25,26]$.

\section{Results}

Fifty-eight patients were eligible for the study. Fifty-four patients were included and four excluded from the study (two for interrupting the informed consent and two for blood clotting alterations). The mean age of patients was $35.7 \pm 5$ years; $79.6 \%$ were male, $20.4 \%$ were female, and $85.2 \%$ were Caucasians. Days of symptoms were on average 23.9 days and the most common symptoms were dry cough $(46.3 \%)$ and productive cough in $14.8 \%$ of the patients. The mean $\mathrm{CD}_{4}^{+}$ cell count was $124.8 / \mathrm{mm}^{3}$ (Table 1 ).

The most frequent patterns observed on chest $\mathrm{x}$ ray and/ or CT scan were interstitial (44.4\%), followed by alveolar patterns (22.2\%). The most prevalent etiological agent was $P$. jiroveci, followed by pyogenic bacteria. Tables 2 and 3 show agents isolated from IS and from BAL, respectively, the latter is considered to be the gold standard .

No complications were observed after the procedure for sputum induction, and only one patient developed pneumothorax after TBLB and was treated with a chest tube.

Sensitivity, specificity, positive/negative predictive values and accuracy for the diagnosis of community-acquired pneumonia using IS in comparison to the gold standard are shown in Table 4. 
Table 1. Characteristics of the HIV patients

\begin{tabular}{lc}
\hline Characteristics & N ( \% ) \\
\hline Age, years* & $35.7 \pm 5$ \\
Gender & \\
$\quad$ Male & $43(79.6)$ \\
$\quad$ Female & $11(20.4)$ \\
Ethnicity & \\
$\quad$ Caucasian & $46(85.2)$ \\
$\quad$ Non Caucasian & $8(14.8)$ \\
Days of symptoms* & $23.9 \pm 7$ \\
LTCD4 ${ }^{+}$count $\left(/ \mathrm{mm}^{3}\right)^{*}$ & $124.8 \pm 9$ \\
\hline * mean. &
\end{tabular}

Table 2. Agents isolated in the induced sputum of 54 HIVpositive patients with associated lung disease

\begin{tabular}{lcc}
\hline Agents & No. & \% \\
\hline Pneumocystis jiroveci & 16 & 40 \\
Mycobacterium tuberculosis & 9 & 22.5 \\
Pseudomonas aeruginosa & 3 & 7.5 \\
Streptococcus viridans & 3 & 7.5 \\
Streptococcus pneumoniae & 3 & 7.5 \\
Klebsiella pneumoniae & 2 & 5 \\
Proteus vulgaris & 1 & 2.5 \\
Enterococcus sp. & 1 & 2.5 \\
Klebsiella oxytoca & 1 & 2.5 \\
Serratia liquefasciens & 1 & 2.5 \\
Total & 40 & 100 \\
\hline
\end{tabular}

Table 3. Agents isolated in BAL and/or TBLB of 54 HIVpositive patients with associated lung disease

\begin{tabular}{lcc}
\hline Agents & No. & $\%$ \\
\hline Pneumocystis jiroveci & 28 & 46.7 \\
Mycobacterium tuberculosis & 10 & 16.7 \\
Streptococcus pneumoniae & 6 & 10 \\
Streptococcus viridans & 4 & 6.7 \\
Pseudomonas aeruginosa & 3 & 5 \\
Klebsiella pneumoniae & 2 & 3.3 \\
Salmonella sp. & 1 & 1.7 \\
Cytomegalovirus & 1 & 1.7 \\
Proteus vulgaris & 1 & 1.7 \\
Enterococcus sp. & 1 & 1.7 \\
Staphylococcus aureus & 1 & 1.7 \\
Cryptococcus neoformans vr. grubii & 1 & 1.7 \\
Serratia liquefasciens & 1 & 1.7 \\
Total & 60 & 100 \\
\hline
\end{tabular}

Table 4. Induced sputum efficiency for bacterial pneumonia diagnosis in $54 \mathrm{HIV}$-positive patients with pulmonary disease

\begin{tabular}{lccc}
\hline Induced sputum & $\begin{array}{c}\text { Gold standard } \\
\text { Positive }\end{array}$ & $\begin{array}{c}\text { Gold standard } \\
\text { Negative }\end{array}$ & Total \\
\hline Positive & 12 & 3 & 15 \\
Negative & 8 & 2 & 10 \\
Total & 20 & 5 & 25 \\
\hline
\end{tabular}

Sensibility $=60 \%$; Specificity $=40 \%$; Positive predict value $=80 \%$ Negative predict value $=20 \%$; Accuracy $=56 \%$.

\section{Discussion}

We found that induced sputum is a simple procedure without significant complications and with good diagnostic yield for bacterial pneumonia in HIV-positive patients.

It is well known that the respiratory tree under the larynx is virtually sterile, and when pulmonary secretions go through the upper airways they become contaminated by oral flora bacteria. This condition creates a bias when analyzing sputum samples for pyogenic bacteria. Microorganisms found in salivary material are derived from gums, dental plaques and palatine tonsils [27]. Thus, minimizing salivary contamination is highly desirable. To achieve this objective, the mechanical removal of saliva, associated with a previous orientation to the patient to vigorously wash the mouth and to mobilize any collected nasopharynx secretions may minimize this problem. Another way of reducing possible contamination is through microscopic evaluation of sputum. It is known that the key to identify "true" sputum is the presence of alveolar macrophages and small quantities of epithelial cells [22,28]. Microscopy sensitivity increases with high quality samples, as much as does the immediate delivery of samples to the laboratory [29]. Contamination is key to the criticism about the usefulness of sputum as a diagnostic method for pulmonary infection, as nearly $45 \%$ of samples sent to laboratories were found to be contaminated by saliva. [30] Sputum induction by itself does not improve the quality of this material, resulting in a yield similar to spontaneous expectoration when appropriate samples are selected [30].

Quantitative culture is a useful technique that enables differentiation between colonization and infection [29,31]. An etiological role may be attributed to microorganisms when they are found at a high concentration, whereas when they are found at low concentrations, they would only be contaminations [32]. On the other hand, some authors have concluded that even low concentrations are enough to cause infection in immunosuppressed patients. In HIV-positive patients, Pirali et al. [32] found acute pulmonary infection with concentrations of as low as $10^{4}$ or $10^{5} \mathrm{CFU} / \mathrm{mL}$, as well as a positive clinical correlation with bacterial concentrations in the samples.

Rimland et al. [33] demonstrated bacterial etiology in $27 \%$ of the cases, when prospectively studying community- 
acquired pneumonia in HIV-positive patients. Brazilian studies have not shown bacteria as a frequent etiological agent [34]. Danés et al. [35] reported bacterial pneumonia as the most frequent diagnosis in HIV-positive patients, with $63 \%$ of the cases, followed by pneumocystosis as the second-most frequent cause of pulmonary disease.

In our study, the most frequently isolated bacterium was Streptococcus pneumoniae (six cases), followed by Streptococcus viridans (four cases) and Pseudomonas aeruginosa (three cases). Streptococcus pneumoniae has been described as the most frequently isolated agent in HIVpositive patients with bacterial community-acquired pneumonia [22,29].

When we analyzed IS efficiency for pyogenic bacteria diagnosis, we found a sensitivity of $60 \%$, a specificity of $40 \%$, a positive predictive value of $80 \%$, a negative predictive value of $20 \%$ and an accuracy of $56 \%$. Cordero et al. [22] demonstrated that sputum culture is a useful technique; along with sterile samples, it renders good correlation, especially when the samples are considered of good quality, within rigid acceptance criteria. These authors evaluated 313 patients with communityacquired pneumonia, and sputum bacterioscopy and culture defined the etiology in $34.5 \%$ of the cases. The value of pulmonary secretions culture was also demonstrated by Thorsteinsson et al. [36] in a prospective study comparing tracheal and bronchial aspirates. Lentino et al. [37] cautions that sputum culture of nonselective common bacterial samples, and from patients without strong evidence of pneumonia, would be of no use. This advice should be considered not only for bacterial agents. Sputum examination in HIV-positive patients is useless and ineffective to clinically recognize this particular illness [38].

We conclude that IS is a useful technique for collecting samples from the lower airway tracts in HIV patients, and it helps to identify the etiology of bacterial pneumonia.

\section{References}

1. Davis L., Beck J.M., Shellito J. Update: HIV infection and pulmonary host defenses. Semin Respir Infect 1993;8:7585.

2. Haramati L.B., Jenny-Avital E.R. Approach to the diagnosis of pulmonary disease in patients infected with the human immunodeficiency virus. J Thorac Imaging 1998; 13:247-60.

3. Barreto S.M., Molinari J.F. I Consenso brasileiro sobre pneumonias: pneumonias em portadores da Síndrome da Imunodeficiência Adquirida (SIDA/AIDS). J Pneumol 1998;24:95-100.

4. Murray J.F., Mills J. Pulmonary infectious complications of human immunodeficiency virus infection (Part I). Am Rev Respir Dis 1990;141:1356-72.

5. Murray J.F., Mills J. Pulmonary infectious complications of human immunodeficiency virus infection (Part II). Am Rev Respir Dis 1990;141:1582-98.

6. Skerret J.S. Diagnostic testing for community-acquired pneumonia. Clin Chest Med 1999;20:531-48.
7. Speich R. Diagnosis of pulmonary problems in HIV-infected patients. Monaldi Arch Chest Dis 1993;48:221-32.

8. Cohn D.L., Stover D.E., O'Brien R.F., et al. Pulmonary complications of AIDS: advances in diagnosis and treatment. Am Rev Respir Dis 1998; 138:1051-2.

9. Pitchenik A.E., Ganjei P., Torres A., et al. Sputum examination for the diagnosis of Pneumocystis carinii pneumonia in the acquired immunodeficiency syndrome. Am Rev Respir Dis 1986; $133: 226-9$.

10. Bigby T.D., Margolskee D., Curtis J.L., et al. The usefulness of induced sputum in the diagnosis of Pneumocystis carinii pneumonia in patients with the acquired immunodeficiency syndrome. Am Rev Respir Dis 1986; 133:515-8.

11. Conde M.B., Soares S.L., Mello F.C., et al. Comparison of sputum induction with fiberoptic bronchoscopy in the diagnosis of tuberculosis: experience at an acquired immune deficiency syndrome reference center in Rio de Janeiro, Brazil. Am J Respir Crit Care Med 2000;162:2238-40.

12. Gold J.A., Rom W.N., Harkin T.J. Significance of abnormal chest radiograph findings in patients with HIV-1 infection without respiratory symptoms. Chest 2002;121:1471-7.

13. Gracia J.D., Miravittles M., Mayordomo C., et al. Empiric treatments impair the diagnostic yield of BAL in HIV-positive patients. Chest 1997;111:1180-6.

14. Mendelson J. Principles of neoplasia. In: Harrison TR, ed. Principles of internal medicine. $2^{\text {a }}$ ed. New York:McGrawHill; 1991.p. 1576-87.

15. O'Dell M.W., Lubeck D.P., O'Driscoll P., Matsuno S. Validity of the Karnofsky performance status in an HIV-infected sample. J Acquir Immune Defic Syndr Hum Retrovirol 1995; $10: 350-7$.

16. Gundy K.V, Boylen C.T. Fiberoptic bronchoscopy. Indications, complications, contraindications. Postgrad Med 1988;83:28994.

17. Efthimiadis A., Pizzichini E., Pizzichini M.M.M., Hargreave F.E. Sputum examination for indices of airway inflammation: laboratory procedures. Canadian Thoracic Society 1997.

18. Petrillo V.F. A relevância clínica na preparação artesanal do esfregaço do escarro (judiciosamente selecionado) na bacteriologia dessa secreção: estudo comparativo com o aspirado de punção pulmonar transcutânea [Dissertação de Mestrado]. Porto Alegre: Universidade Federal do Rio Grande do Sul, 1987.

19. Marshall J.R. Manual de laboratório clínico - microbiologia. $1^{\text {a }}$ ed. São Paulo: Santos Livraria Editora; 1995.

20. Luna L.G. Manual of histologic staining methods the armed forces institute of pathology. $3^{\mathrm{a}}$ ed. New York: McGraw-Hill Book Co New York; 1968.

21. Behmer O.A., Tolosa E.M.C., Neto A.G.F. Manual de técnicas para histologia normal e patológica. $1^{\mathrm{a}}$ ed. São Paulo: EDART; 1976.

22. Cordero E., Pachon J., Rivero A., et al. Usefulness of sputum culture for diagnosis of bacterial pneumonia in HIV-infected patients. Eur J Clin Microbiol Infect Dis 2002; $21: 362-7$.

23. Baughman R.P., Dohn M.N. Immunocompromised host. In: Baughman RP, ed. Bronchoalveolar lavage. St. Louis: Mosby Year Book Inc; 1992. p. 41-63.

24. Dawson-Saunders B., Trapp R.G. Basic and clinical biostatistics. Connecticut: Appleton \& Lange; 1990. 
25. Fletcher R.H., Fletcher S.W., Wagner E.H. Epidemiologia clínica. Bases científicas da conduta médica. $2^{\mathrm{a}}$ ed. Porto Alegre: Artes Médicas; 1989.

26. Menezes A.M.B., Santos I.S. Curso de epidemiologia básica para pneumologistas. $4^{\text {a }}$ parte - epidemiologia clínica. J Pneumol 1999;25:321-6.

27. Gordon D.F., Jong B.B. Indigenous flora from human saliva. Applied Microbiology 1968; $16: 428-9$.

28. Epstein M.R.L. Constituents of sputum: a simple method. Ann Intern Med 1972;77:259-65.

29. Baselski V., Mason K. Pneumonia in the immunocompromised host: the role of bronchoscopy and newer diagnostic techniques. Sem Respir Infect 2000; 15 : 144-61.

30. Chuard C., Fracheboud D., Regamey C. Effect of sputum induction by hypertonic saline on specimen quality. Diagn Microbiol Infect Dis 2001;39:211-4.

31. Lode H., Schaberg T., Raffenberg M., Mauch H. Diagnostic problems in lower respiratory tract infections. J Antimicrob Chemother 1993;32 Suppl A:29-37.

32. Pirali F., Longo M., Gelmi M., et al. Diagnosis of bronchopulmonary infections by quantification of microflora. Eur J Epidemiol 1994; 10:703-6.
33. Rimland D., Navin T.R., Lennox J.L., et al. Prospective study of etiologic agents of community-acquired pneumonia in patients with HIV infection. AIDS 2002; $16: 85-95$.

34. Weinberg A., Duarte M.I.S. Respiratory complications in Brazilian patients infected with human immunodeficiency virus. Rev Inst Med Trop São Paulo 1993; $35: 129-39$

35. Danés C., González-Martín J., Pumarola T., et al. Pulmonary infiltrates in immunosuppressed patients: analysis of a diagnostic protocol. J Clin Microbiol 2002;40:2134-40.

36. Thorsteinsson S.B., Musher D.M., Fagan T. The diagnostic value of sputum culture in acute pneumonia. JAMA 1975;233:894-5.

37. Lentino J.R., Lucks D.A. Nonvalue of sputum culture in the management of lower respiratory tract infections. J Clin Microbiol 1987;25:758-62.

38. Kvale P.A., Hansen N.I., Markowitz N., et al. Routine analysis of induced sputum is not an effective strategy for screening persons infected with human immunodeficiency virus for Mycobacterium tuberculosis or Pneumocystis carinii. Clin Infect Dis 1994;19:410-6. 